\title{
EQUiLIBRIUM
}

Quarterly Journal of Economics and Economic Policy

2016 VOLUME 11 ISSUE 2, June

p-ISSN 1689-765X, e-ISSN 2353-3293

www.economic-policy.pl

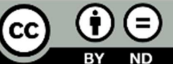

Kijek, T. (2016). Intellectual Property Rights and Appropriability of Innovation Capital: Evidence from Polish Manufacturing Firms. Equilibrium. Quarterly Journal of Economics and Economic Policy, 11(2), 387-399. DOI: http://dx.doi.org/10.12775/ EQUIL.2016.018

Tomasz Kijek* $^{*}$

University of Life Sciences in Lublin, Poland

\section{Intellectual Property Rights and Appropriability of Innovation Capital: Evidence from Polish Manufacturing Firms}

JEL Classification: 031 ; 034

Keywords: innovation capital; appropriability mechanism; intellectual property rights; patent; knowledge production function

\begin{abstract}
This paper tries to find how firms use IPRs in the form of patents to protect innovation capital and find determinants of their effectiveness. The research is based on a large sample of 2960 Polish manufacturing firms that were engaged in developing and/or implementing a product or process innovation in the years 2010-2012. Besides descriptive statistics which show firms' attitudes toward the effectiveness of patents and their determinants, I apply the knowledge production function to find a link between patent propensity, $R \& D$ and innovation performance. Descriptive analyses show that Polish manufacturing firms rarely use patents as the appropriability mechanism, which results in the low level of their perceived effectiveness. It also turns out that the perceived effectiveness of a patent depends on a firm's size, the innovation type and technological opportunities. In turn, the results of the knowledge production function estimation allow me to conclude that an increase in patent propensity affects the firm's innovation performance positively.
\end{abstract}

(C) Copyright Institute of Economic Research

Date of submission: March 17, 2015; date of acceptance: January 14, 2016

* Contact: tomasz.kijek@up.lublin.pl, University of Life Sciences in Lublin, ul. Akademicka 13, Lublin, Poland

*** The project was financed by National Science Center on the basis of decision number DEC-2013/09/D/HS4/01139. 


\section{Introduction}

Innovation capital constitutes to draw the attention of scholars and practitioners, because the ability to innovate is a source of a firm's value and growth in a knowledge based economy (Sullivan, 2000, pp. 4-22). Innovation capital can be broadly defined as a bundle of a firm's knowledge assets that render services in the process of new knowledge (innovation) creation and commercialization. Due to the semi-public good characteristics of knowledge, the possession of monopolistic power over innovation capital is feasible but never perfect. As a consequence, there are different appropriability mechanisms, combining formal methods in the form of intellectual property rights - IPRs (e.g. patents) and informal methods (e.g. secrecy, lead time, product complexity) which can be used by economic agents to protect the innovative knowledge they create. The lack of appropriability mechanisms would lead to underinvestment in research and innovation, and hence, inefficiency of firms and economies.

Although there is a vast body of literature on the reasons behind a firm's choice of appropriability methods and the effectiveness of their use (see López, 2009, pp.1-32), most of these studies focus on subjective measures of benefits of various appropriability tools. Only a few studies deal with innovation performance and try to relate it to the firms' preferences for the particular appropriability method. Thus, the purpose of the paper is to fill this gap in the literature by determining how the utilization of intellectual property rights (IPRs) in the form of patents allows Polish manufacturing firms to appropriate profits from innovation. A model used in this research is a knowledge production function, in which two main components of innovation capital, i.e. patents and research and development (R\&D), are included among the regressors. Additionally, I use descriptive statistics to analyze the perceived effectiveness of patents toward increasing the competitiveness of product and process innovations.

\section{Research Methodology}

In this study, anonymized micro-data from the survey of innovation activities of Polish manufacturing enterprises in the years 2010-2012 were used. The survey was conducted in 2013 by Polish Statistical Office. Enterprises having more than nine employees participated in the study. The enterprises were selected on the basis of the Polish Classification of Activities, which is consistent with the statistical classification of economic activities in the European Community (NACE Rev. 2). The types of questions used in this 
survey were based on the Community Innovation Survey - CIS. The interpretability and validity of the CIS questionnaire were verified by extensive piloting and pre-testing before implementation within different European countries (Laurent \& Salter, 2006, pp.131-150). The sample of innovation active firms used in this analysis includes 2960 entities that were engaged in developing and/or implementing a product or process innovation in the years 2010-2012.

The elements of innovation capital analyzed in this study are patents and $\mathrm{R} \& \mathrm{D}$ used in the process of technological innovation introduction. In the case of patents, each firm was asked to respond to a question about the effectiveness of patents for increasing the competitiveness of product and process innovation. The respondents were given four ordinal categories: 4not used, 3-low, 2-medium, and 1-high effectiveness. Moreover, the study exploits information on the number of patent applications to the Polish Patent Office in 2010-2012. As far as R\&D is considered, information feeding into analysis is $R \& D$ intensity measured as the ratio of $R \& D$ expenditures divided by the total sales.

To assess perceived effectiveness of patents, the means of firms' responses to the question about the effectiveness of patents for increasing the competitiveness of product and process innovations are calculated. The results are presented by the firm's size, the innovation type and technological opportunity. Additionally, a two-sample t-test is used to compare the means. Apart from descriptive statistics, the method of analysis is the generalized structural equation modeling-GSEM (Rabe-Hesketh et. al., 2004, pp.167-190). My empirical model consists of two equations. The former is estimated using the Tobit model, also called a censored regression model (Greene, 2008, pp. 871-872), where the dependent variable is innovation performance (INN), which is explained by the percentage of a firm's sales corresponding to products new to the market. The choice of the Tobit model results from the nature of the dependent variable which is, by definition, (double) censored, i.e. it ranges between 0 and 100. Although the choice of the dependent variable makes sense in terms of appropriability analysis, it limits my analysis to only product innovators ( $\mathrm{i}=2062)$. The model includes the R\&D intensity (RDI) and the number of patent applications (PATENT) among regressors. The latter is estimated as the Poisson regression where the dependent variable is the number of patent applications and the R\&D intensity is included as the regressor. The use of the Poisson regression results from the preponderance of zeros and the small values of the patent variable. The two-equation model is specified as follows: 


$$
\begin{gathered}
\text { INN }_{i}=\alpha_{11} \text { PATENT }_{i}+\alpha_{12} \text { RDI }_{i}+\alpha_{13} \text { TO }_{i}+\alpha_{14} S_{i}+\varepsilon_{i} \\
\text { PATENT }_{i}=\alpha_{22} \text { RDI }_{i}+\alpha_{23} \text { TO }_{i}+\alpha_{24} S_{i}+\varepsilon_{i}
\end{gathered}
$$

TO and $S$ appear as control variables in both equations. The first variable relates to technological opportunities quantified by patent statistics at the industry level. I use the OECD's industry classification, i.e. hightechnology and medium-high-technology, medium-low-technology, and low-technology. Patent applications are then averaged over the industry. The second variable is the firm's size divided into three categories, i.e. small $\left(S_{-} S\right)$, medium $\left(S_{-} M\right)$, and large $\left(S_{-} L\right)$. Since the size variable is a categorical variable, dummy coding is used. It compares each level of the categorical variable to a fixed reference level (i.e. the small firms).

\section{The Concept of Innovation Capital ${ }^{1}$}

Innovation capital is a term that arises from a conjunction of two seminal economic concepts, i.e. capital and innovation, and is interchangeably used with such constructs as innovative knowledge assets (He \& Wang, 2009, pp. 919-938) and innovation-related intangibles (Lev, 2001, p. 18). Innovation capital was introduced to the economic and managerial nomenclature for the first time by Edvinsson \& Malone (1997, p. 1-23) in their intellectual capital - IC - model. They describe innovation capital as renewal capabilities of a company in the form of intellectual properties and other intangible assets used to create and introduce new products and services to the market. This definition sensu largo has been specified by a few authors (e.g. Wagner \& Hauss, 2000, pp. 709-712; McElroy, 2002, pp. 30-39), who adopted different perspectives (i.e. technological, organizational or sociological).

According to Kijek (2012, pp. 52-68), innovation capital consists of two groups of knowledge assets necessary for innovation. The former pertains to codified technological knowledge in the form of innovative intellectual property rights-IPRs and stock of $\mathrm{R} \& \mathrm{D}$ knowledge. The latter relates to knowledge embodied in the organizational routines/practices, norms and thinking of employees. Codified technological knowledge is the knowledge about how to produce new products and install new processes, which comprises know-what (e.g. a description of ingredients or specification of a new

\footnotetext{
${ }^{1}$ The concept of innovation capital described in this section is mainly based on considerations presented by Kijek (2012, pp. 52-68).
} 
product) and know-why (e.g. technology of a new product manufacturing). The combination of know-why with employees' knowledge forms knowhow (e.g. a practical use of new technology). As suggested by the reward theory of patents, exclusive rights to new facts (know-what) and new technologies (know-why) in the form of patents are deemed effective for securing the return from inventions and provide sufficient incentives for firms to conduct risky investments in $R \& D$ (Zaby, 2010, p. 2). In line with this approach, the increase in commitments to $\mathrm{R} \& \mathrm{D}$ does not precede increased patenting, but is simultaneous with it (Basberg, 1982, pp. 163-171).

It is important to notice that a patent does not always allow a firm to obtain a monopoly over the market. For example, human insulin can be produced either by applying enzymes for eliminating a specific amino acid from the structure of pig insulin, or by genetically-modified bacteria, so neither of the patent owners of these inventions, i.e. Novo Nordisk and Genentech, have a monopoly over the insulin market. Moreover, the formal system of IPRs allows the firm to extend its technological knowledge base by the acquisition of external knowledge in the form of patents and utility models or not patented technological know-how (Zakrzewska \& Kijek, 2016, pp. 328-329).

Innovation capital differs from physical assets in a few important aspects. First, innovative knowledge assets are, in general, non-rival, as they can be deployed at the same time by many users. This is especially true for know-what and know-why. However, multiple use may reduce the market value of knowledge by increasing its supply to the market. Another peculiarity of innovation capital is the fact that it generally requires large initial investments, while the cost of its use is negligible. For example, the development of a drug is expensive and takes a long time, but doubling its production does not require any change in the underlying $R \& D$ and patents (Lev, 2001, p. 23). Last, but not least, the difference between innovative knowledge assets and physical assets is the availability and the enforceability of property rights (Teece \& Augier, pp. 3-27). Physical assets are generally well protected and property rights enforcement is relatively easy. In the case of intangible assets, property rights are limited (patents, designs, trademarks, etc.) and their enforcement is relatively difficult. 


\section{Appropriability of Innovation Capital}

As mentioned previously, innovative property in the form of patent is regarded as an element of innovation/knowledge-based capital (OECD, 2011, p. 2; Kijek, 2012, pp. 52-68; Edvinsson \& Malone, 1997, pp. 1-23). A patent gives the owner monopoly rights to use an invention for a given period. Patents and other forms of IPRs allow the owner to receive an adequate returns from its creation by placing the IPRs in the public domain. In the light of the above, a patent is regarded as a means of appropriability, since it is a building block of the firms' capacity to retain profits from knowledge embedded in invention or innovation (López, 2009, p. 2). A lack of appropriability mechanisms in the form of patents could lead firms to under-invest in innovation capital. Although this paper focuses on IPRs, it should be noted that there are other informal appropriabiality mechanisms, including secrecy, lead time, product complexity etc. which may be used when legal protection is not feasible or efficient.

Theoretical and empirical papers suggest that the effectiveness of IPRs in protecting innovative knowledge is related to either internal or external factors. The most thoroughly examined internal determinant of IPRs use is the type of innovation. Cohen et al. (2000, p. 10) reveal that patents are reported to be more effective for product innovation than process innovation by U.S. manufacturing firms. This finding is unsurprising, since knowledge about process invention is less publicly available than that of product invention, so patent infringements are more difficult to detect for process innovation. Another important factor that affects the propensity to patenting is a firm's size. Many authors state that the application of patents increases with the firm's size. For example, Gonzalez-Alvarez \& NietoAntolin (2007, pp. 280-295) find that Spanish firms of larger size were more willing to patent. In turn, Hanel (2008, pp. 285-309) proves that medium and large-sized firms employ all IPR elements more frequently than small firms. The reason for these findings may be twofold. First, in the line of Schumpeter's (1942, pp. 131-134) arguments, large firms have access to financial resources which are necessary for obtaining, maintaining and monitoring IPRs. Moreover, small firms may be in an unfavorable position when it comes to enforcing their IPRs. Second, large firms are deemed to be better equipped with tangible capital and human capital, which allows them to introduce original innovations requiring legal protection. Last, but not least, an internal determinant of IPRs addressed in the literature is a firm's R\&D intensity. Most of the studies find a positive relationship between R\&D and patent propensity (Duguet \& Kabla, 1998, p. 14; Hall \& 
Ziedonis, 2001, pp. 101-128). However, there is also evidence that R\&D expenditures make no contribution to patenting (Arundel \& Kabla, 1998, pp. 127-141). In a similar vein, Megna \& Klock (1993, pp. 265-269) argue that patents and $R \& D$ are distinct measures of intangible assets. These contradictory findings may result from the fact that in-house $R \& D$ is neither sufficient nor necessary as an explanation for patenting. For example, firms may as well acquire patentable knowledge at the market. Moreover, firms engaged in R\&D may use different appropriability methods instead of patenting.

In the case of exogenous factors affecting the effectiveness of patent use, it is assumed that firms operating in various manufacturing sectors relay on different appropriability mechanisms. In their seminal paper, Levin et al. (1987, pp. 783-831) find that in chemical and pharmaceutical industries patents are deemed to be more effective in appropriating benefits from innovation than in other industries. Similarly, Harabi (1995, pp. 981-992) proves that in such sectors as chemical and cosmetic products and agricultural equipment, a patent is regarded as an effective tool of appropriability.

\section{Effectiveness of Patents in Polish Manufacturing Firms}

A first look at the perceived effectiveness of patents indicates that patents are, on average, regarded by Polish manufacturing firms as being lowly effective (Table 1). While interpreting this result, it should be noted that the perception of the relative strength of the patent depends on its use and availability. The availability of patent is a function of specific characteristics of an invention, such as novelty, non-obviousness and industrial applicability. Therefore, only inventions which meet these requirements can be patented. Unfortunately, most of the product and process innovations introduced by the sample firms do not fulfill the criteria of patentability. Similarly et al. (2007, pp. 95-112) confirmed the hypothesis of a relationship between the strength and the use and availability of different IPRs. As mentioned previously, the use of patent is connected with a firm's size and economic potential. The results confirm this supposition, since the perceived effectiveness of patents increases monotonically with the size of the firm. Moreover, firms with both product and process innovations rank effectiveness of patents higher than firms with only process innovations and firms with only product innovations. However, I find no significant difference in the perceived effectiveness of patents between firms with product innovations and firms with process innovations. This finding is contrary to 
the results of other studies (e.g. Hanel, 2008, 285-309) which show that patents are more effective for product innovations than for process innovations.

In the light of the results from Table 1, significant differences in the effectiveness attributed to patents are found when dividing firms by sectors. Firms located in medium-high-technology sectors deem patents more effective than firms located in low technology and medium-low-technology sectors. Nonetheless, analyzing sectoral differences in the perceived effectiveness of patents, it should be noticed that there is a large variability in firms' perceptions of patents effectiveness within particular sectors. This variability can be explained by the fact that firms may also pursue patents for other objectives than for appropriability (protecting objectives), e.g. blocking or negotiation motives (Blind et al., 2006, pp. 665-672).

Table 1. Perceived effectiveness of patents by a firm's size, innovation types and sectors

\begin{tabular}{|c|c|c|c|}
\hline \multicolumn{4}{|c|}{ Size of firm } \\
\hline $\begin{array}{l}\text { Small-S } \\
\left(\mathrm{n}_{1}=440\right)\end{array}$ & $\begin{array}{l}\text { Medium-M } \\
\left(\mathrm{n}_{2}=1710\right)\end{array}$ & $\begin{array}{l}\text { Large }-\mathrm{L} \\
\left(\mathrm{n}_{3}=812\right)\end{array}$ & Means difference \\
\hline 3,7 & 3,46 & 3,28 & $\begin{array}{l}\mathrm{S}>\mathrm{M}^{* * * ;} \quad \mathrm{M}>\mathrm{L} * * * ; \\
\mathrm{S}>\mathrm{L}^{* * *}\end{array}$ \\
\hline \multicolumn{4}{|c|}{ Innovation types } \\
\hline $\begin{array}{l}\text { Product - PT } \\
\left(\mathrm{n}_{1}=673\right)\end{array}$ & $\begin{array}{l}\text { Process -PS } \\
\left(\mathrm{n}_{2}=721\right)\end{array}$ & $\begin{array}{l}\text { Product and process - } \\
\text { PT_PS } \\
\left(\mathrm{n}_{3}=1389\right)\end{array}$ & Means difference \\
\hline 3,41 & 3,39 & 3,29 & $\begin{array}{l}\text { PS>PS_PT } * * * ; \\
\text { PT }>\text { PS_PT } * * *\end{array}$ \\
\hline \multicolumn{4}{|c|}{ Sectors } \\
\hline $\begin{array}{l}\text { Low-tech- LT } \\
\left(\mathrm{n}_{1}=878\right)\end{array}$ & $\begin{array}{l}\text { Medium-low } \\
\text { tech-MLT } \\
\left(\mathrm{n}_{2}=1030\right) \\
\end{array}$ & $\begin{array}{l}\text { High and medium- } \\
\text { high-tech - HMHT } \\
\left(\mathrm{n}_{3}=1053\right)\end{array}$ & Means difference \\
\hline 3,51 & 3,41 & 3,34 & $\begin{array}{l}\text { LT>MLT } * * * ; \\
\text { MLT>HMHT***; } \\
\text { LT>HMHT*** }\end{array}$ \\
\hline
\end{tabular}

Note: $* * *$ denotes that means are different at $1 \%$ significance level.

Source: own calculation on the basis of data provided by the Statistical Office in Szczecin ${ }^{2}$. tion.

${ }^{2}$ The Statistical Office in Szczecin is not responsible for any conclusions in this publica- 
The descriptive analysis presented above is of limited use when one is interested in finding a qualitative relationship between $\mathrm{R} \& \mathrm{D}$, patents and firms' innovation performance. In order to fulfill this task, I apply the knowledge production function - KPF originally developed by Griliches and Pakes (1980, pp. 377-381). In their model, the link between R\&D and patent is called the "knowledge production function". Empirically, I use an extended version of the KFP which connects both R\&D and patents to a firm's innovation performance. My version of the model regards patent as an intermediary input in an innovation process. Due to the complexity of knowledge /innovation production process, I use a system of two equations. The first equation connects $R \& D$ and patents with innovation performance measured by the percentage of sales corresponding to products new to the market. This measure of innovation output allows us to assess the extent to which the use of patents is associated with retaining profits from knowledge embedded in innovations. The second equation models a link between R\&D and patents. According to innovation capital theory, I introduce $R \& D$ investments among the regressors in two equations, since I assume that $R \& D$ affects the firm's performance directly and indirectly via patents.

Consistently with the literature in this area, I control for technological opportunities and a firm's size. The expectation is that firms operating in a sector with plenty of technological opportunities are assumed to be more innovative. Such an assumption is supported by findings of Evangelista and Sirilli (1998, pp. 881-889) who report that technological opportunity appears to be the most important driving force of innovation across a sample of Italian firms. As regards the firm's size, it is expected that large firms have access to financial resources and sophisticated equipment necessary for innovation activity. However, the advantages of scale and scope exhibited by large firms in the past seem to be less important nowadays. Many firms are now following an open innovation approach, sourcing much of their innovation externally (Chesbrough, 2003, p. 22).

Table 2 shows the results of the generalized structural equation model estimation. As expected, firms' R\&D intensity appears to be influencing innovation performance positively, as the parameter for the variable is positive and significant. As far as the patent variable is considered, the results indicate that there is a positive relationship between the number of patent applications and innovation performance. Similarly, Hall et al. (2013, pp. 603-629) find that firms' propensity to patenting is positively associated with innovation performance measured by sale due to product innovation. It is important to notice that the patent variable is the "stronger" variable than the $R \& D$ variable in the first equation. This finding supports 
the claim that patent is an effective mechanism to appropriate the returns from product innovation in the sample firms. Relating to the second equation in the model, the R\&D intensity has a positive impact on patenting, which is a similar result to that of Licht \& Zoz (1998, pp. 307-338).

The analyzes also show that technological opportunities at the industry level increase firms' propensity to patenting. This can be explained by the fact that technological knowledge disclosed in patent applications builds the stock of general knowledge which may be useful for other investors of the same field. The same holds true for the innovation performance. Turning to the second control variable, the results suggest that medium and large firms are more likely to apply for patents than small firms which is consistent with my expectation. In the case of innovation performance, the size effect is equivocal. It turns out that medium-sized firms have smaller sales corresponding to products new to the market than small firms. However, the size effect disappears in the case of large firms.

Table 2. GSEM estimates of the knowledge production function

\begin{tabular}{lcccc}
\hline Variable & Coef. & Std. err. & $\mathbf{z}$ & $\mathbf{p}>|\mathbf{Z}|$ \\
\hline INN $<$ & & & & \\
\hline IRD & 0,33 & 0,11 & 3,01 & 0,00 \\
\hline PATENT & 1,15 & 0,51 & 2,23 & 0,03 \\
\hline TO & 19,41 & 6,65 & 2,92 & 0,00 \\
\hline S_M & $-5,71$ & 2,67 & $-2,14$ & 0,03 \\
\hline S_L & $-1,71$ & 2,87 & $-0,60$ & 0,55 \\
\hline CONST & $-6,03$ & 3,36 & $-1,79$ & 0,07 \\
\hline PATENT & & & & \\
\hline IRD & 0,02 & 0,00 & 9,22 & 0,00 \\
\hline TO & 2,79 & 0,30 & 9,36 & 0,00 \\
\hline S_M & 1,46 & 0,26 & 5,64 & 0,00 \\
\hline S_L & 2,41 & 0,26 & 9,38 & 0,00 \\
\hline CONST & $-3,91$ & 0,28 & $-14,11$ & 0,00 \\
\hline Log likelihood & \multicolumn{5}{c}{} \\
\hline
\end{tabular}

Source: own calculation on the basis of data provided by the Statistical Office in Szczecin.

\section{Conclusions}

This paper produces a few important contributions for the theory and practice on appropriability of innovation capital. First of all, it focuses on both the perceived effectiveness of a patent and the relationship between patent and innovation performance. The research results show that Polish manu- 
facturing firms rarely use patents as an appropriability mechanism. It has a direct impact on the perceived effectiveness of patent, which is relatively low. It is worth noting that the perceived effectiveness of patents increases with the firm's size and availability of technological opportunities. As regards the innovation performance, two components of innovation capital, i.e. R\&D and patents, positively affect the percentage of sales corresponding to products new to the market. These findings suggest that Polish firms should invest resources in R\&D activities and try to apply for patents if it is possible.

The paper is not exempt from some limitations. The main drawback pertains to the fact that firms usually introduce more than a single innovation in a given period and use a set of different appropriability methods. So it is difficult to isolate the impact of a particular appropriability tool (e.g. patent) on innovation performance. To overcome this limitation, future research should focus on an innovation-level analysis and include a broader set of appropriability mechanisms in the knowledge production function.

\section{References}

Augier, M., \& Teece, D. J. (2005). An Economics Perspective on Intellectual Capital. In B. Marr (Ed.). Perspectives on Intellectual Capital: Multidisciplinary Insights into Management and Reporting. Boston: Butterworth-Heinemann.

Arundel, A., \& Kabla, I. (1998). What Percentage of Innovations are Patented? Empirical Estimates for European Firms. Research Policy, 27(2). DOI: http://dx.doi.org/10.1016/S0048-7333(98)00033-X.

Basberg, B. (1982). Technological Change in the Norwegian Whaling Industry: A Case Study of the Use of Patent Statistics as a Technology Indicator. Research Policy, 11(3). DOI: http://dx.doi.org/10.1016/0048-7333(82)90017-8.

Blind, K., Edler, J., Frietsch, R., \& Schmoch, U. (2006). Motives to Patent: Empirical Evidence from Germany. Research Policy, 35(5). DOI: http://dx.doi.org/ 10.1016/j.respol.2006.03.002.

Cohen, W., Nelson, R., \& Walsh, J. (2000). Protecting Their Intellectual Assets: Appropriability Conditions and Why US Manufacturing Firms Patent (or Not). Retrived from http://citeseerx.ist.psu.edu/viewdoc/download?rep=rep1\& type $=$ pdf $\&$ doi $=10.1 .1 .216 .2585(01.03 .2015)$.

Chesbrough, H. (2003). Open Innovation, The New Imperative for Creating and Profiting from Technology. Boston: Harvard Business School Press.

Duguet, E., \& Kabla, I. (1998). Appropriation Strategy and the Motivations to Use the Patent System: An Econometric Analysis at the Firm Level in French Manufacturing. Retrived from http://www.insee.fr/fr/publications-etservices/docs_doc_trav ail/g9717.pdf (13.03.2015). 
Edvinsson, L., \& Malone, M. S. (1997). Intellectual Capital: The Proven Way to Establish Your Company's Real Value by Measuring Its Hidden Brainpower. London: Judy Piatkus Ltd.

Gonzalez-Alvarez, N., \& Nieto-Antolın, M. (2007). Appropriability of Innovation Results: An Empirical Study in Spanish Manufacturing Rirms. Technovation, 27(5). DOI: http://dx.doi.org/10.1016/j.technovation.2006.12.004.

Greene W. H. (2008). Econometric Analysis. New Jersey: Prentice Hall.

Griliches, Z., \& Pakes, A. (1980). Patents and R\&D at the Firm Level: A First Report. Economics Letters, 5(4).

Hall, B. H., Helmers, C., Rogers, M., \& Sena, V. (2013). The Importance (or not) of Patents to UK Firms. Oxford Economic Papers, 65(3). DOI: http://dx.doi.org /10.1093/oep/gpt012.

Hall, B. H., \& Ziedonis, R. H. (2001). The Patent Paradox Revisited: An Empirical Study of Patenting in the US Semiconductor Industry. Rand Journal of Economics, 32(1). DOI: http://dx.doi.org/10.2307/2696400.

Hanel, P. (2008). The Use of Intellectual Property Rights and Innovation by Manufacturing Firms in Canada. Economics of Innovation \& New Technology, 17(3). DOI: http://dx.doi.org/10.1080/10438590701581481.

Harabi, N. (1995). Appropriability of Technical Innovations. An Empirical Analysis. Research Policy, 24(6). DOI: http://dx.doi.org/10.1016/00487333(94)00812-4.

He, J., \& Wang, H. (2009). Firm Innovative Knowledge Assets and Economic Performance: The Asymmetric Roles of Incentive- and Monitoring-based Governance Mechanisms. Academy of Management Journal, 52(5). DOI: http://dx.doi.org/10.5465/AMJ.2009.44633414.

Hurmelinna, P., \& Puumalainen, K. (2007). Nature and Dynamics of Appropriability: Strategies for Appropriating Returns on Innovation. R\&D Management, 37(2). DOI: http://dx.doi.org/10.1111/j.1467-9310.2007.00460.x.

Kijek, T. (2012). Innovation capital and its measurement. Journal of Entrepreneurship. Management and Innovation, 8(4).

Laursen, K., \& Salter, A. (2006). Open for Innovation: the Role of Openness in Explaining Innovation Performance Among UK Manufacturing Firms. Strategic Management Journal, 27(2). DOI: http://dx.doi.org /10.1002/smj.507.

Lev, B. (2001). Intangibles: Management, Measurement, and Reporting. Washington: Brookings Institution Press.

Levin, R. C., Klevorick, A. K., Nelson, R. R., Winter, S. G., Gilbert, R., \& Griliches, Z. (1987). Appropriating the Returns from Industrial Research and Development. Brookings Papers on Economic Activity, 18(3).

Licht, G., \& Zoz, K. (2000). Patents and R\&D. An Econometric Investigation using Applications for German, European and US Patents by German Companies. In D. Encaoua, B. Hall, F. Laisney \& J. Mairesse (Eds). The Economics and Econometrics of Innovation. Boston: Kluwer Academic Publishers.

López, A. (2009). Innovation and Appropriability: Empirical Evidence and Research Agenda. Retrieved from http://www.wipo.int/export/sites/www/ipdevelopment /en/economics/pdf/wo_1012_e_ch_1.pdf (11.03.2015). 
McElroy, M. (2002). Social Innovation Capital. Journal of Intellectual Capital, 3(1). DOI: http://dx.doi.org/10.1108/14691930210412827.

Megna, P., \& Klock, M. (1993). The Impact of Intangible capital on Tobin's q in the Semiconductor Industry. American Economic Review, 83(2).

Organisation for Economic Co-operation and Development (OECD) (2012). New Sources of Growth: Knowledge-Based Capital. Paris: Directorate for Science, Technology, and Industry. Retrieved from http://www.oecd.org/sti/inno /newsourcesofgrowthknowledge-basedcapital.htm (10.03.2015)

Schumpeter, J. A. (1942). Capitalism, Socialism, and Democracy. New York: Harper.

Sirilli, G., \& Evangelista, R. (1998). Technological Innovation in Services and Manufacturing: Results from Italian Surveys. Research Policy, 27(9). DOI: http://dx.doi.org/10.1016/S0048-7333(98)00084-5.

Sullivan, P. H. (2000). Value-Driven Intellectual Capital: How to Convert Intangible Corporate Assets Into Market Value. New York: John Wiley \& Sons.

Wagner, K., \& Hauss, I. (2000). Evaluation and Measurement of R\&D Knowledge in Engineering Sector. In M. Khosrowpour (Ed.). Proceedings of the $2000 \mathrm{In}$ formation Resources Management Association International Conference on Challenges of Information Technology Management in the 21st Century. Amsterdam: IOS Press.

Zaby, A. (2010). The Decision to Patent. Contributions to Economics. Heidelberg and New York: Springer.

Zakrzewska, A., \& Kijek, T. (2016). Market Valuation of Innovation-Related Intangibles: The Case of Polish Biotechnology Firms. In T. Dudycz, G. OsbertPociecha \& B. Brycz (Eds). The Essence and Measurement of Organizational Efficiency. Heidelberg-New York-Dordrecht-London: Springer International Publishing. DOI: http://dx.doi.org/10.1007/978-3-319-21139-8 20. 